Gontar, N.N. \& Kapitonov, A.M. (2021). Peculiarities of interpretation of liability for violation of budget legislation in the Russian Federation. The Law and its Interpretation. Collection of Scientific Articles. European Scientific e-Journal, 5 (11), 57-71. Hlučín-Bobrovníky: “Anisiia Tomanek" OSVČ.

Гонтарь, Н.Н., Капитонов, А.М. (2021). Особенности интерпретации ответственности за нарушение бюджетного законодательства в Российской Федерации. The Law and its Interpretation. Collection of Scientific Articles. European Scientific e-Journal, 5 (11), 57-71. Hlučín-Bobrovníky: "Anisiia Tomanek" OSVČ.

DOI: $10.47451 /$ jur2021-02-002

EOI: $10.11244 /$ jur2021-02-002

The paper is published in Crossref, Internet Archive, Google Scholar, Academic Resource Index ResearchBib, JGate, ISI, CiteFactor, ICI, eLibrary databases.

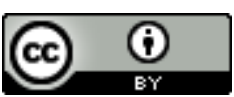

Nina N. Gontar

Associate Professor

Candidate of Sciences in Jurisprudence

Department of State and Municipal Administration

North-West Institute of Management

The Russian Presidential Academy of National Economy and Public Administration

St Petersburg, Russia

E-mail: ninagontar@mail.ru

Andrey M. Kapitonov

Master's degree student

Faculty of Training Specialists for the Judicial System

Russian State University of Justice

St Petersburg, Russia

E-mail: ninagontar@mail.ru

\title{
Peculiarities of interpretation of liability for budget legislation violation in the Russian Federation
}

\section{Abstract:}

Recently, the legal liability topic for budget legislation violation is one of the most relevant topics of financial and legal (budget and legal) science and law enforcement practice. The increased attention to the issues of responsibility in the field of finance is caused by the desire to strengthen control over the development of budgetary legal relations, make the budget activities of the state and municipalities as effective as possible, and ensure financial discipline in the state. The article analyzes the features of liability for violation of the budget legislation of the Russian Federation, budget enforcement measures, as well as administrative and criminal liability for violation of the budget legislation. The author concludes that the Russian Federation has a sufficiently developed system of responsibility for budget offences undergoing constant changes and improvements. However, several issues require extensive discussion to improve the effectiveness of budget legislation and its convergence with international counterparts. The materials of the article are intended for students and specialists in the field of law dealing with the problems of Russian legislation. 
Keywords:

budget legislation violation, Russian Federation, fiscal enforcement measures, administrative liability, criminal liability.

Нина Николаевна Гонтарь

АОцент, кандидат юридических наук

Кафедра государственного и муниципального управления

Северо-Западный институт управления

Российская Академия народного хозяйства и государственной службоы

Санкт-Петербург, Россия

E-mail: ninagontar@mail.ru

Андрей МихайАович Капитонов

Магистрант

Факультет подготовки специалистов Аля судебной системы

Российский государственный университет правосудия

Санкт-Петербург, Россия

E-mail: ninagontar@mail.ru

\section{Особенности интерпретации ответственности за нарушение бюджетного законодательства в Российской Федерации}

\section{Aннотачия:}

В последнее время тема юридической ответственности за нарушение бюджетного законодательства выступает одной из актуальных тем финансово-правовой (бюджетноправовой) науки и правоприменительной практики. Повышенное внимание к вопросам ответственности в сфере финансов вызвано стремлением усилить контроль наА развитием бюджетных правоотношений, слелать бюджетную деятельность государства и муниципальных образований максимально эффективной, обеспечить финансовую Аисциплину в государстве. В статье проанализированы особенности ответственности за нарушение бюджетного законодательства Российской Федерации, бюджетных мер принуждения, а также административной и уголовной ответственности за нарушение бюджетного законодательства. САелано заключение, что в Российской Федерации имеется Аостаточно развитая система ответственности за бюджетные правонарушения, которая претерпевает постоянные изменения и совершенствуется. ОАнако имеется ряд вопросов, которые требуют широкого обсуждения с целью повышения эффективности бюджетного законодательства и его сближения с межАународными аналогами. Материалы статьи предназначены для студентов и специалистов в области права, занимающихся проблемами российского законодательства.

Ключевые слова:

нарушение бюджетного законодательства, Российская Федерация, меры финансового принуждения, административная ответственность, уголовная ответственность. 


\section{Introduction}

Recently, the legal liability topic for budget legislation violation is one of the most relevant topics of financial and legal (budget and legal) science and law enforcement practice. The increased attention to the issues of responsibility in the field of finance is caused by the desire to strengthen control over the development of budgetary legal relations, to make the budgetary activities of the state and municipalities as effective as possible - ultimately to ensure financial discipline in the state. The importance and relevance of this topic can be drawn, in particular, from the report on the work of the Accounting Chamber for 2020.

The Audit Chamber became the president of the International Organization of Supreme Audit Institutions (INTOSAI) and achieved the adoption of the Moscow Declaration, which will determine the strategy for the development of supreme audit institutions around the world for the coming years and even decades. Now the report pages present not only the main results of its activities but also the general approaches are clearly illustrated with specific examples. A separate section of the report is devoted to the results of the transformational work that began in 2018 with the adoption of the new Development Strategy of the Accounting Chamber and continues to gain momentum. In 2019, new approaches were introduced, the share of strategic audit increased, large-scale projects in the field of digitalization were implemented, and the openness of the Accounting Chamberwas increased. In addition, the Chamber's performance indicators have been revised. The main criterion for successful work should be the reduction of violations through prevention. So, in 2020 , more than 200 violations were detected at the stage of budget formation and, thus, the unjustified distribution of about 40 billion rubles was prevented. In total, in 2020 , the Accounting Chamber conducted more than 300 events, identified about 4.5 thousand violations worth about 1 trillion rubles. According to the materials of the inspections, dozens of criminal cases were initiated (Report on the work of the Accounting Chamber in 2019).

The main purpose of the study was to determine the features of the interpretation of responsibility for violation of budget legislation in the Russian Federation at the present stage of the development of statehood.

Based on this goal, the following tasks were identified that are necessary for the implementation of the study:

- determine the specifics of liability for violation of the budget legislation of the Russian Federation;

- $\quad$ analyze budget enforcement measures implemented in recent years; 
- analyze the specifics of administrative and criminal liability for violations of the budget legislation of the Russian Federation;

- $\quad$ assess the effectiveness of the implementation of legislative acts in the field of economic security at the current stage of the development of statehood in Russia.

To implement the research, comparative, historical, logical and deductive methods of analyzing the materials used in the scientific article were used.

In the course of the study, legislative acts and codes were used, as well as research materials of leading experts in the field of budget legislation N.A. Sattarova and D.L. Komyagin.

\section{Liability for violation of budget legislation: general characteristics}

In paragraph 1 of article 306.1 of the Budget Code (hereinafter - BC) of the Russian Federation provides a legal concept of a budget offense, which is understood as a violation of the provisions of the budget legislation of the Russian Federation and other legal acts regulating budget legal relations, provisions' violation of legal acts committed by the highest executive body of state power of a subject of the Russian Federation (local administration), a financial body, the chief administrator (administrator) of budget funds, a state (municipal) customer, public regulatory obligations and obligations for other payments to individuals from the budgets of the budget system of the Russian Federation, which caused damage to public legal education, violation of the terms of contracts (agreements) on the provision of funds from the budget, violation of the requirements established by the legislation of the Russian Federation on the contract system in the field of procurement of goods, works, services for state (municipal) needs for planning, justification of purchases of goods, works, services for state (municipal) needs, as well as requirements to change, terminate the state (municipal) contract, violation of the terms of state (municipal) contracts, violation of the terms of contracts (agreements) concluded for the purpose of executing contracts (agreements) on the provision of funds from the budget, resulting in damage to public law education, non-compliance with the goals, procedure and conditions for granting loans secured by state and municipal guarantees

The budget legislation violation is the non-fulfilment or improper fulfilment of the procedure established by the Budget Code for drawing up and reviewing draft budgets, approving budgets, executing and monitoring the execution of budgets of the budget system of the Russian Federation is recognized as a violation of the 
budget legislation of the Russian Federation, which entails the use of coercive measures against the violator. Liability for budget legislation violation is a broad concept that is inter-sectoral, "it is a generic concept in which the legislator has included such types of legal liability as budget, administrative and criminal" (Sattarova, 2015). At the same time, the question of the types of liability for violation of budget legislation is not fully resolved in the theory of financial (budget) law. There is no doubt about such types of liability for budget legislation violation as administrative and criminal. At the same time, the existence of proper budget responsibility with the change in budget legislation is questionable, since any responsibility comes for an offence committed and provides for the state's response in the form of coercion to undergo certain deprivations by the violator, "which are a natural reaction to the harm caused by the offender to society and the state" (Matuzova et al., 2001). There are different viewpoints regarding the existence and independence of the actual budget (budget-legal) responsibility. So, D.L. Komyagin says that budget responsibility is not a legal responsibility because it is pointless to apply punitive measures to special entities that are participants in the budget process, while "having a truncated, incomplete legal personality (e.g., in the form of a fine, which was provided for in the previous version of the $\mathrm{BC}$ ). Nor does it make sense to apply compensatory measures to such persons, since the participants in the budget process are public authorities, state-owned institutions, which operate at the expense of the budget and are endowed with public property. Any collection from them will mean collection from the budget to another budget or even to the same budget" (Komyagin, 2014). Another viewpoint is shared by N.A. Sattarova, who writes that "budget and legal responsibility... it acts simultaneously as a kind of financial and legal liability as an independent type of liability" and "the legal basis for the application of financial and procedural coercion, as a rule, is the fact of committing a financial offence..." (Sattarova, 2008). Most financial law scholars adhere to this point of view. Thus, we can say that the basis for bringing to responsibility for budget legislation violation may be:

- $\quad$ budget offence;

- violation of budget legislation that contains signs of an administrative offence (budget offence);

- a crime related to violation of budget legislation (budget crime).

As with any liability, in this case, liability for budget offences, both general properties of liability and certain features are inherent. I will not dwell on the general provisions on liability but will tell you about the specific liability features for 
violations of budget legislation. They are determined by the specifics of the scope of budget violations-the specifics of the content and direction of budget activities of the state and municipalities. Within the framework of budgetary activities, the implementation of budgetary legal relations is carried out, aimed at the formation, distribution and use of centralized monetary funds - the budget of the Russian Federation, the budgets of the subjects of the Russian Federation, the budgets of municipalities, as well as the budgets of state extra-budgetary funds for financial support for the implementation of the tasks and functions of the state at various territorial levels.

Thus, the specifics of liability for violation of budget legislation are expressed in the following:

1) specific grounds for applying liability measures in budget legislation violation (the Russian Federation BC uses specific terminology 'budget violation');

2) a combination of the norms of the budget law, administrative law, and criminal law when assigning responsibility measures for budget legislation violations (for committing budget violations, budget enforcement measures are applied following the Russian Federation BC). Along with the use of budgetary coercive measures for committing offences in the sphere of the functioning of the budget system, in cases established by law, legal liability measures are applied based on the Code of Administrative Offenses and Criminal Code of the Russian Federation);

3) a specific range of subject to prosecution (subjects whose powers are somehow related to the budgetary activities of the state and municipalities, participants in the budget process, directly) is a combination of the competence of financial authorities and judicial authorities in the application of tools (measures) of legal responsibility.

\section{Fiscal enforcement measures}

Then it is necessary to describe in more detail the formulated features of liability for violation of budget legislation. The grounds for the liability under consideration have a specific content - non-fulfilment or improper fulfilment of the provisions of the budget legislation.

The general object of budget violation is public relations arising as a result of the funds' provision violation from the budget of the budget system of the Russian Federation, actions (inaction) of the financial authority, the chief administrator of budget funds, the administrator of budget funds, the recipient of budget funds, the 
chief administrator of budget revenues, the chief administrator of sources of financing of the budget deficit.

The objective side of the budget violation is expressed in the illegality of the committed act itself (action or omission).

The subjects of budget violation are specific subjects-participants of the budget process: the financial authority, the chief administrator of budget funds, the administrator of budget funds, the recipient of budget funds, the chief administrator of budget revenues, the chief administrator of sources of financing of the budget deficit.

At the same time, it should note that such entities as autonomous, budgetary institutions, state (municipal) unitary enterprises, legal entities and other entities (individual entrepreneurs, individuals) that are allocated budget allocations, for example, in the form of subsidies based on articles 78, 78.1, 78.2 of the Russian Federation $B C$, are not participants in the budget process within the meaning of article 152 of the Russian Federation BC. And logically, budget enforcement measures do not apply to them.

The subjective side of a budget violation is not always an element of the composition of a budget violation.

Article 306.4. Misuse of budget funds:

1. Non-targeted use of budget funds is recognized as the direction of budget funds of the budget system of the Russian Federation and payment of monetary obligations for purposes that do not fully or partially meet the goals defined by the law (decision) on the budget, consolidated budget list, budget list, limits of budget obligations, budget estimates, contract (agreement) or legal act that is the basis for the provision of these funds.

3. Improper use of budget funds, the source of financial support (co-financing) of which was an inter-budget transfer with a specific purpose, entails an undisputed recovery of the number of funds used for other purposes or a reduction in the provision of inter-budget transfers (except for subventions and subsidies for equalizing the budget security of the subjects of the Russian Federation and municipalities).

Article 306.5. Non-repayment or late repayment of the budget loan:

Non-repayment or untimely repayment of the budget loan entails an undisputed recovery of the amount of the outstanding balance of the budget loan and penalties for its untimely repayment in the amount of one three-hundredth of the current refinancing rate of the Central Bank of the Russian Federation for each day of delay and (or) suspension the of inter-budget transfers' provision (except for subventions and 
subsidies to equalize the budget security of the subjects of the Russian Federation and municipalities) to the budget to which the budget loan was granted, in the amount of the outstanding balance of the budget loan.

Article 306.6. Non-transfer or late transfer of payment for the use of a budget loan:

Non-transfer or late transfer of the fee for the use of the budget loan entails an undisputed recovery of the amount of the fee for the use of the budget loan and penalties for its late transfer in the amount of one three-hundredth of the current refinancing rate of the Central Bank of the Russian Federation for each day of delay and (or) suspension of the provision of inter-budget transfers (except for subventions and subsidies for equalizing the budget security of the subjects of the Russian Federation and municipalities) to the budget to which the budget loan is granted, for the amount of the outstanding balance of the payment for the use of the budget loan.

Article 306.7. The violation of the conditions for granting a budget loan:

The violation of the conditions for granting a budget loan granted to one budget of the budget system of the Russian Federation from another budget of the budget system of the Russian Federation, including the use of the corresponding budget funds for purposes not provided for by the legal act (contract) that is the basis for granting these funds, entails an undisputed recovery of the number of funds used in violation of the conditions for granting a budget loan, and (or) fees for using them and (or) suspension of the provision of inter-budget transfers (except for subventions and subsidies for equalizing the budget security of the subjects of the Russian Federation and municipalities).

It should note that in the above-mentioned articles of the Russian Federation $B C$, there are no sanctions for the budget violations specified in them since the responsibility for the violation of these articles is mainly administrative and criminal. However, it is necessary to give an example from which budget responsibility is seen. So, in the Ruling of the Russian Federation Supreme Court of 28.01.2020, No. 306-ES1926376 in case No. A55-28970/2018, it is stated that "In connection with the establishment of the fact of violation by the Ministry of Transport of the requirements provided for in article 306.4 of the Russian Federation BC, namely - the department sent a letter to the Treasury dated 29.06.2018 No. 42-13-39/23-3967 on the direction of the draft notification on the application of budgetary coercive measures for the improper use of the 52,437,855 ruble subsidy at the object Reconstruction of the Moscow Highway on the Section from Kirov Avenue to the Gas Station No. 115 Rosneft in Samara, Providing Access to the Stadium. As a result of the consideration of this letter, the Treasury sent a notification on the application of budgetary coercive measures dated 
01.08.2018 N 07-04-04/09-16233 to the Ministry of Finance. By order of the Ministry of Finance, a budget enforcement measure was applied to the Ministry of Transport, and budget funds of 52,437,855 rubles were collected in an undisputed manner by transferring them to the federal budget revenue". The subject of consideration of the Russian Federation Supreme Court was the application of the Government and the Ministry of Transport to invalidate the decision of the Federal Treasury Department for the Samara region on the existence of grounds for sending a notification on the application of budgetary coercive measures, expressed in the letter of $29.06 .2018 \mathrm{~N}$ 42-13-395/23-3967, the Federal Treasury notification of 01.08.2018 N 07-04-04/0916233 and the order of the Ministry of Finance of the Russian Federation of 31.08.2018 N 1788. The Supreme Court of the Russian Federation confirmed that the Courts came to the correct conclusion that the use of the subsidy funds to finance other objects not included in the list specified in the Agreement of 16.07.2015 No. FDA 48/54-C-1 is inappropriate (Decisions of the Supreme Court of the Russian Federation No. 306EC19-26376).

\section{Administrative and criminal liability for budget legislation violation}

The articles of the Code of Administrative Offences of the Russian Federation correspond to the articles of the Budget Code, which allows you to correctly and timely identify violations in the budget sphere and bring those responsible to justice.

Administrative liability for budget legislation violation is applied to persons guilty of committing an administrative offence in the budget sphere.

An administrative offence under Article 2.1 of the Code of Administrative Offenses is an illegal, culpable act (inaction) of an individual or legal entity, for which the Code of Administrative Offenses or the laws of the subjects of the Russian Federation on administrative offences establish administrative responsibility.

It should note that the Code of Administrative Offences of the Russian Federation establishes 18 offences of budget legislation:

- $\quad$ budget funds' misuse (article 15.14);

- $\quad$ non-repayment or late repayment of a budget loan (article 15.15);

- non-transfer or late transfer of payment for the use of a budget loan (article 15.15.1);

- $\quad$ the conditions' violation for granting a budget loan (article 15.15.2);

- the conditions' violation for granting inter-budget transfers (article 15.15.3);

- the conditions' violation for granting budget investments (article 15.15.3). 15.15.4); 
- the conditions' violation for granting subsidies (article 15.15.5);

- the procedure violation for submitting budget reports (article 15.15.6);

- the procedure violation for drawing up, approving and maintaining budget estimates (article 15.15.7);

- $\quad$ the ban violation on granting budget loans and (or) subsidies (article 15.15.8);

- non-compliance of the budget list with the consolidated budget list (article 15.15.9);

- $\quad$ the procedure violation for making budget commitments (article 15.15.10);

- the deadline violation for completing budget allocations and (or) limits of budget obligations (article 15.15.11);

- $\quad$ the ban violation on placing budget funds (articles 15.15 .11 and 15.15.12);

- violation of the terms of servicing and repayment of state (municipal) debt (article 15.15.13);

- the deadline violation for sending information about the results of the case in court (article 15.15.14);

- $\quad$ the procedure violation for forming a state (municipal) task (article 15.15.15);

- the execution violation of payment documents and the Federal Treasury body's submission (article 15.15.16).

The subject of administrative responsibility is citizens, individual entrepreneurs, legal entities and officials. According to article 1.5 of the Code of Administrative Offences, a person is subject to administrative responsibility only for those administrative offences in respect of which his guilt is established (presumption of guilt). In this case, a person is considered innocent until his guilt is proved in the manner provided for in the proceedings on an administrative offence and established by the decision of the judge, body, official who reviewed the case, which has entered into legal force. For the commission of the above-mentioned types of violations, the Code of Administrative Offences does not provide for the application of legal sanctions against violators of budget legislation. They can only be subject to punitive measures in the form of a fine, and for certain offences in the form of disqualification. It should note that cases of administrative offences in the budgetary sphere are considered by the body that performs the functions of control and supervision in the financial and budgetary sphere. In the case of disqualification, the cases are considered in court.

It is necessary to show an example. From the Ruling of the Supreme Court of the Russian Federation of 20.12.2019 No. 302-ES19-23087, it follows that LLC Trading House of Sahabult by the resolution of the Ministry of Finance of the Republic of 
Sakha (Yakutia) of 31.10.2018 No. 1/15.14-2018/408 was brought to administrative responsibility under article 15.14 of the Code of Administrative Offenses with the imposition of a fine.

Article 15.14 of the Code of Administrative Offences provides for administrative liability for the budget funds' misuse, expressed in the direction of the RF budget system and payment of monetary obligations for purposes that do not fully or partially correspond to the goals defined by the law (decision) on the budget, consolidated budget list, budget list, budget estimates, contract (agreement) or another document that is the legal basis for the provision of these funds, or in the direction of funds, funds received from the budget of the RF budget system, for purposes that do not correspond to the purposes defined by the contract (agreement) or another document that is the legal basis for the provision of these funds, if such an action does not contain a criminal offence. The grounds for bringing to responsibility were the circumstances revealed by the administrative body, indicating that the company used part of the subsidy funds provided for financial support of the costs of harvesting commercial furs, for expenses not related to the harvesting of commercial furs. The RF Supreme Court in the transfer of the cassation appeal of the Company on the recognition of illegal and cancellation of the Decision to bring the Company to administrative responsibility under art. 15.14 Code of Administrative Offences for consideration in the court session of the Judicial Board for Economic Disputes of the Supreme Court was refused since the company's actions established the composition of this administrative offence (Decisions of the Supreme Court of the Russian Federation No. 302-EC19-23087).

Criminal liability for violation of budget legislation occurs in cases where the budget legislation violation committed by an official is characterized by increased public danger and falls under the signs of a criminal offence committed in the budget sphere. Criminal liability is incurred for the misuse of budget funds (article 285.1 of the Criminal Code), the state extra-budgetary funds' misuse (article 285.2 of the Criminal Code). Depending on the circumstances, under which the crime was committed and the qualification of the crime, coercive measures under these articles may include both a fine and imprisonment with a subsequent ban on engaging in certain activities.

From the Ruling of the Supreme Court of May 18, 2018, in case No. 4U-298/2018, it follows that the verdict of the Leninsky District Court of the Federation subject of November 2, 2017, the citizen was convicted under Part 1 of article 285.1 of the Criminal Code to a fine. The citizen was found guilty of spending budget funds by an official of the recipient of budget funds for purposes that do not meet the conditions 
for receiving them, defined by another document that is the basis for receiving budget funds, committed on a large scale. The court found that the agreement of the second level was concluded based on the resolution of the Council of Ministers of the Federation subject of December 17, 2015, No. 794 and the agreement of the first level, which specified specific objects for which budget funds were allocated, based on the agreement of the 2 nd level, the treasury allocated funds that were not spent for purposes that meet the conditions for their receipt. By the appeal decision of the Supreme Court of the Federation subject of December 12, 2017, the verdict of the court regarding the guilt of the citizen, according to article 285.1, part 1 of the Criminal Code was left unchanged. The Supreme Court of the Federation subject refused to transfer the cassation appeal of the convicted person for consideration in the court session of the court of cassation instance (Decisions of the Supreme Court of the Russian Federation No. 4U-298/2018).

\section{Discussion}

Within the framework of the study, three main directions of further study of the issue of interpretation of responsibility for violation of budget legislation in the Russian Federation were identified, which can be studied at the international level by researchers and scientists studying the peculiarities of the transformation of the legislative framework of the Russian Federation:

- Ways to maximize the convergence of the legislative framework of the Russian Federation with European law regarding the budget Code.

- Problems of unification of the interpretation of the budget legislation of the Russian Federation by various international legal systems.

- Search for legislative associations to improve the effectiveness of the budget law of the Russian Federation.

Research in these areas requires the experience of not only Russian but also European specialists with extensive experience in the formation of various legal systems in a single European space.

\section{Conclusion}

Thus, after analyzing the regulatory framework, as well as supporting it with judicial practice, we can draw some conclusions:

The Russian Federation has a well-developed system of responsibility for budget offences, which is not stagnating but is undergoing constant changes and improvements. So, in the Budget Code of the Russian Federation, in the articles regulating 
the budget. So, even the Unified Portal of the Budget System of the Russian Federation does not keep up with the changes in the current legislation and does not have time to publish articles in the current version at the moment.

Also, it is worth noting that the mechanism for bringing persons to justice is current and well-established, as evidenced by a large number of court practice published in the public domain.

Summing up the main result, it is worth focusing on the fact that the international community also recognizes the leading position of the Russian Federation in budget supervision. Thus, in the published Review of Budget Openness for 2019, covering 117 countries, Russia took 14th place in this rating, gaining 74 points, which is 2 points more than in the previous review (Open Budget Survey 2019). The Accounting Chamber contributed to this growth, and its ratings have increased by all criteria over the past two years.

"Russia has made positive changes in the process of forming the state budget and has improved its position in the issue of publishing key information that helps the public understand the essence of budget policy, decisions and results," the Review emphasizes.

The review consists of three indexes:

1. "Budget oversight by the legislature and the Supreme Audit Institution"

Over the past two years, Russia has managed to increase this index from 78 to 85 points and enter the top seven countries with the best indicator in this area. In particular, this was due to the improvement of the assessment of the activities of the supreme audit institution - the Accounting Chamber of the Russian Federation (from 83 to 89 points). In particular, independent experts positively assessed the fact that now a separate structural unit in the Accounting Chamber regularly reviews the audit processes.

2. "Public participation in the budget process"

It evaluates relevant practices from the legislative branch, the executive branch, and the supreme audit institution. In Russia as a whole, over the past two years, this indicator has increased from 13 to 22 points, and in terms of the contribution of the Accounting Chamber, it has almost doubled - from 33 points to 67 points. The improvement of the assessment was influenced by the development of mechanisms through which the public can send suggestions on audit topics. Now citizens can send appeals in writing, through the website of the Accounting Chamber, as well as use the functionality of the Portal of State and Municipal Financial Audit. All these changes are in line with the Development Strategy of the Audit Chamber, adopted 
in 2018. One of its tasks is to strengthen the culture of openness and transparency of decision-making processes.

\section{3. "Open Budget Index"}

It examines the transparency and accessibility of eight key budget documents, including the Audit Chamber's opinion on the annual budget performance report. In Russia, over the past two years, this index as a whole has increased from 72 to 74 points, and the assessment of the audit report separately-from 67 to 81 points. The Audit Chamber has planned some measures that will help to make this assessment even higher in the future. In particular, it is the publication of the conclusion on the annual report on the federal budget implementation in a machine-readable format.

\section{References:}

The Code of Administrative Offences of the Russian Federation, no. 195-FL. (2001, December 30). Ed. On April 24, 2020. (in Russian)

The Budget Code of the Russian Federation. No. 145-FL (1998, July 31). Ed. On April 22, 2020. (in Russian)

The Criminal Code of the Russian Federation. No. 145-FL (1996, June 13). Ed. On April 7, 2020. (in Russian)

Matuzova, N.I. \& Malko, A.N. (Eds.). (2001). Theory of State and law: A course of lectures. Moscow. (in Russian)

Sattarova, N.A. (2008). Financial and procedural compulsions (questions of theory and practice). Kazan. (in Russian)

Sattarova, N.A. (2015). Measures of state coercion in the budgetary sphere as a factor of effective functioning of the financial system. Lex Russica, 8, 96-106. (in Russian)

Komyagin, D.L. (2014). Budget violations and budget enforcement measures: innovations in budget legislation. Reforms and Law, 2, 10-15. (in Russian)

Decisions of the Supreme Court of the Russian Federation. No. 306-EC19-26376 in case No. A55-28970/2018 (2020, January 28). (in Russian)

Decisions of the Supreme Court of the Russian Federation. No. 302-EC19-23087 (2019, December 20). (in Russian)

Decisions of the Supreme Court of the Russian Federation. No. 4U-298/2018 (2018, May 18). (in Russian)

Report on the work of the Accounting Chamber in 2019 (2020). The Audit Chamber of the Russian Federation. Retrieved December 15, 2020, from http://audit.gov.ru/reports/10114 (in Russian) 
Open Budget Survey 2019. International Budget Partnership. Retrieved December 21, 2020, from http://www.internationalbudget.org/open-budgetsurvey/open-budget-survey-2019-0 (in Russian) 